Environmental concerns - Uniting generations for a global cause in turbulent times

\author{
Susana Costa e Silva \\ Católica Porto Business School - Universidade Católica Portuguesa \\ Rua Diogo Botelho, 1327 \\ 4169-005 Porto - Portugal \\ ORCID ID: orcid.org/0000-0001-7979-3944 \\ E-mail: ssilva@porto.ucp.pt \\ Paulo Duarte \\ Universidade da Beira Interior \\ NECE- Research Unit in Business Sciences \\ Av. Marquês D'Ávila e Bolama \\ 6201-001 Covilhã (Portugal) \\ ORCID ID: orcid.org/0000-0001-8449-5474 \\ E-mail:pduarte@ubi.pt
}

Carla Martins

Católica Porto Business School - Universidade Católica Portuguesa

Rua Diogo Botelho, 1327

4169-005 Porto - Portugal

E-mail: cmartins@porto.ucp.pt

Paulo Collaço

Católica Porto Business School - Universidade Católica Portuguesa

Rua Diogo Botelho, 1327

4169-005 Porto - Portugal

E-mail: pcollaco.15@hotmail.com 


\section{Acknowledgements}

The authors would like to thank to CEGE - Research Centre in Management and Economics, funded by the Multiannual Funding Programme of R\&D Centres of FCT - Fundação para a Ciência e a Tecnologia, under the project UIDB/00731/2020 and to NECE - Research Unit in Business Sciences funded by the Multiannual Funding Programme of R\&D Centres of FCT - Fundação para a Ciência e a Tecnologia, under the project UID/GES/04630/2019. 


\title{
Environmental concerns - Uniting generations for a global cause in turbulent times
}

\begin{abstract}
A radical set of social and structural shifts in the last years has transformed the world, bringing a confusing order that few have been able to predict. Common sense information and myths about millennials' generation define them as being very homogeneous and different from other generations, which would be already a complex dimension to analyze. However, the complexity increases according to some studies that suggest that other generations have a flawed perception of millennials. Based on this, the purpose of this article is to assess the self-image Millennials regarding consumption behavior and compare it with how they are perceived by other generations, namely, Boomers and Generation Xers. Identifying and understanding the differences could assist in improving the ability to market to them.
\end{abstract}

To conduct this study, a survey was developed to collect data from each group of interest located in the same institutional setting to avoid institutional distance. The constructs included were Technology Savviness, Social Responsibility, Environmental Concern, Status Consumption, and Brand Loyalty. The final sample consisted of 342 participants where 182 were Millennials (53.8\%) and the remaining 160 were either Baby Boomers or Generation Xers (42.8\%).

The current results support the idea of differences between self and other perception, although not in every dimension. The results show that Millennials and older generations have different perceptions regarding Millennial technology savviness, social responsibility, status consumption, and brand loyalty. Environmental concern was the only dimension were the self-opinion of Millennials did not differ from the other generations. Current findings are pertinent because differences in millennial's behaviors are important for companies addressing international markets. These results challenge research conducted in other cultural landscapes and call for the need to validate the typical pattern, which lays over the idea that there are significant differences among millennials' self-perception and perception of others about them. Because this information provides useful knowledge for brands to become more effective, it is crucial for managers of companies conducting business in a global context to be acquainted with it. This will promote the possibilities to create and maintain close relationships with the Millennials, taking into account the institutional setting in which they grew up. Finally, this study emphasizes the importance of environmental concerns in the current world, which may have the power to unite different generations for a single global cause, thus sorting out some of the confusion.

Keywords: Generational gap; Millennials; Technology Savviness, Brand Loyalty, Social Concern, Environmental Responsibility; Generational Differences 


\section{Introduction}

Mainly referred to as Millennials, this generation is referred by different names, such as Echo Boomers, Generation Me, Generation Y. It seems to be complicated to accurately define this generation's birth year, since different authors tend to consider different dates, however for the purpose of this study, Millennials are the people born between the years 1981 and 2000. Millennials represent the generation who is becoming the main consumers of today, presenting themselves as an attractive market since they are considered the largest consumer population spending around 200 billion U.S. Dollars per year. Hence, it is crucial to study this generation, to understand what are the best ways for reaching them and provide a more personalized experience (Moreno, Lafuente, Carreón, \& Moreno, 2017). To attain this objective, it is important to keep in mind that being a generational cohort is a group of individuals that were born about the same time, or during a specific period, sharing more or less the same characteristics and manifesting their values and beliefs more or less in the same behavioral towards events and facts that tend to affect them similarly. As they are shaped by educational systems, families, world events, among other factors, they suffer from a combination of influences that include idiosyncratic elements from their own country, along with elements that affect the world and, in particular, that generation. In what concerns the millennial generational cohort, due to the intense development of new technologies and having grown up in a digital world, this generation drifts away from older generations, being much more educated, accustomed to multi-tasking having easy access to virtually everything, from information to experiences. Having grown in a globalized, and highly diversified world, Millennials tend to have a more personal view regarding the society, ethnicity and even sexual orientation, leading them to be the most socially concerned generation in comparison to the ones before it (Barnes \& Pressey, 2016; Scheresberg, Lusardi, \& Yakoboski, 2014).

This article aims to answer two main questions. Firstly, what are the differences between the way Millennials see themselves and the way other generations see them. The response to this question will help to understand how this generation can be more accurately described by comparing the different points of view. The second research question concerns to discussion on how institutions as "rules of the game" are regarded by these generations because in most of the cases they did not create them and therefore will be in general critical of them, hence tending to create the so-called "generation gaps". 


\section{Generational Cohorts}

Millennials represent a generational cohort, which consists of people that, due to their date of birth, would share certain experiences in specific timeframes, and therefore would develop common characteristics, beliefs and behaviors (Eastman \& Liu, 2012). Cohorts are highly influenced by the external events that were happening at the time they were growing up, resulting in different cohorts being marked by different experiences and, therefore, displaying different attitudes and behaviors (Eastman \& Liu, 2012).

When addressing generational cohorts, it is common to consider four main generations: Baby Boomers, Generation X, Generation Y or Millennials (the subject of this study) and the most recent one, Generation Z. Baby Boomers grew up and were marked by the Second World War since this cohort is considered by most to born between 1946 and 1960 and are considered highly independent and, even, individualistic (Williams \& Page, 2012). Generation X, born between 1961 and 1980, was marked by high divorce rates, diminishing birth rates, economic recession and the uprising of unemployment. Influenced by this environment, Generation $X$ was pushed to be more pragmatic and realistic with higher consideration for education (Reisenwitz \& Iyer, 2009). Despite the several opinions regarding Millennials born dates, it is commonly accepted that it includes individuals born between the 1980s and the 2000s (Pyöriä, Ojala, Saari, \& Järvinen, 2017; Gurău, 2012; Moreno et al., 2017). Lastly, generation Z consists of a group of people born after 2000. This generation will sometimes be compared to, and even confused with the Millennials since they grew in similar environments and therefore share a lot of characteristics. Resembling the generation studied in this study (Millennials), the members of the generation $\mathbf{Z}$ are considered notably technology savvy, focusing on innovation and an overwhelming level of comfort with globalization and its diversity (Wood, 2000).

\section{The Millennial Generation}

Millennials are seen as the largest generation since the number of people that are considered to be part of the Millennials surpasses the previous generations (Eastman \& Liu, 2012; Gurău, 2012; Moreno et 
al., 2017; Pyöriä et al., 2017; Young \& Hinesly, 2012). This generation came about in a timeframe where the previous generation's economic situation was getting under control, thus they grew up in a time of economic prosperity and accompanied by the rapid development and growth of technology, namely the internet. Simultaneously, Millennials also grew up in a society that was changing, characterized by societal uncertainty due to, for instance, the increasing number of divorces (Eastman \& Liu, 2012). Nevertheless, some authors claim Millennials are the most educated generation, consisting in highly competent users of technology, massive users of social media and all types of technological devices which led them to be creative, resourceful and highly competent online communicators (Mizelle \& Beck, 2018; Moreno et al., 2017; Pyöriä et al., 2017). The degree to which social media is used and has been incorporated in this generation's lifestyle is considered one of the main differences between Millennials and previous generations. As a recent study conducted right after the Covid-19 outbreak outlined, there are substantial differences mainly concerning media consumption, differences that became even more evident during the self-social isolation and quarantine periods (Visual Capitalist, 202011). Partially these differences are due to an institutional environment that shapes structures through a kind of isomorphism (Salomon \& Wu, 2012), that turn national institutional systems, somehow deterministic (Arthur, 1994). For this reason, it can be stood that Millennials' behaviors may look alike regardless of their location, since these digital infrastructures exist and shape their attitudes towards global events. Thus, all over the globe, we witness these individuals being heavy users of these digital resources, both as consumers and as producers of information (Sago, 2010). As members of this generation are comfortable with multi-tasking, they are more efficient when it comes to the use of time, but, inevitably, also create a state of impatience and shorter attention spans, in part also as a consequence of being raised in a world of instant gratification (Iyer, Eastman, Monteiro, Rottier, \& Zokarkar, 2016; Williams \& Page, 2012). Therefore Millennials are an easily bored generation that is constantly seeking quick answers (Mizelle \& Beck, 2018) making the internet their primary source of information regarding products and services (Nowak, Thach, \& Olsen, 2006a).

Additionally, Millennials are usually looked at as practical and constantly searching for value in the products and services they acquire (Nowak et al., 2006a), thus being self-centered, and having low levels

\footnotetext{
${ }^{1}$ In https://www.visualcapitalist.com/media-consumption-covid-19/?fbclid=IwAR3-

TI774Qztpq76jSBcNhXjpPJE23IIY81XLOZOsVkSxsaCAR6KRw-eNTE, consulted in 8/4/2020.
} 
of brand loyalty (Gurău, 2012). Millennials live to make a positive contribution to society (Ordun, 2015; Santos \& Silva, 2013). They are regarded as being more concerned with environmental and social responsibility issues than previous generations, as exposed in past boycotts for several brands that this

generation perceives as violating their values and principles (Nowak et al., 2006a). This generation believes that they are the ones who can make the world a better place (Dagher, 2014; McGlone, Spain, \& McGlone, 2011), hence, having an optimistic nature. Moreover, Millennials are the most ethnically diverse cohort with an innate growing concern regarding diversity which leads to a fairer understanding of race and multicultural thinking (Broido, 2004; Hallman, 2017). Additionally, they are known to be less ethnocentric identity (Cleveland, Laroche, \& Papadopoulos, 2015). Usually, this multicultural characteristic is represented in the preference for ads that include diversity, race and gender (Iyer et al., 2016; Licsandru \& Cui, 2019; Nowak et al., 2006a).

\section{The Millennial Consumer}

Researchers claim that Millennials grew up with access to computers and the Internet, and they are therefore inherently technology-savvy (Palfrey \& Gasser, 2008; Tapscott, 1998). Furthermore, the Millennial consumer has proven to be a challenge for brands that target them because they are more aware of traditional marketing techniques from growing up in a marketing saturated environment (Lazarevic, 2012). However, choosing to ignore this segment would be a tremendous mistake for companies (Fernandez, 2009). Thus, it is of critical relevance to study this generation's consumer behaviors and the relation it has with the institutional rules driving the society to effectively develop effective and profitable marketing strategies.

A behavior that most authors seem to agree upon is that Millennials are more consumption-oriented since they were led to believe by the institutional rules that material possession is a reflex of their success. As a result, they are encouraged to buy because that is the way for them to acquire status and personality (Lazarevic, 2012). They were lead to believe that they could use brands as an extension of themselves to create a certain image and reflect personal characteristics in the eyes of their peers (Fernandez, 2009; Gurău, 2012; Lazarevic, 2012). 
Accordingly, they select products that help them define their values, making this generation more involved with the things they buy since a wrong purchase might have negative social consequences (Moreno et al., 2017; Ordun, 2015). They will constantly look for products and brands that match their personality and communicate their values, so, their loyalty will vary. However, due to extensive exposure to price promotions and multiple alternatives to certain products and services Millennials tend to have low brand loyalty (Fernandez, 2009; Gurău, 2012; Moreno et al., 2017). Brand preference constantly changes due to the influence of their peers and the electronic word-of-mouth (e-wom) because this generation is highly influenced by the "people like me" when it comes to determining the quality of a product instead of going in line with the institutional logic of trusting in branding or traditional advertising techniques (Moreno et al., 2017; Smith, 2011). Moreover, Millennials have proven to not tolerate bad brand experiences, being significantly more influenced by positive and negative product comments that can be found in a wide range of social media sources (Sago, 2010). This implies that brands should always focus on building brand authenticity and integrity as mandatory characteristics to develop a lucrative relationship with this generation (Gurău, 2012).

Since Millennials are a very environmentally and socially concerned generation (Smith, 2010, 2014) they tend to have a higher preference for companies and brands that share these "make the world a better place" values and life-motto, making Brand's' mission extremely important in Millennials' decisionmaking process (Ordun, 2015; Smith \& Brower, 2012).

Millennials like to be involved, want to engage with brands, co-creating products and participating in marketing research, so, they will more likely be attracted to brands that use digital marketing to enhance inclusion, personalization, co-development of products and services (Moreno et al., 2017).

However, even in the same generational cohort, multiple groups may coexist, and millennials are sometimes divided into old and new Millennials groups. According to Debevec, Schewe, Madden, and Diamond (2008), older Millennials (over 30 years old) tend to be not as unconcerned about savings and will take a careful approach to their consumption behaviors, an aspect that is not verified in younger Millennials, who are constantly looking for new experiences and live a much more "cherish the moment" lifestyle (Debevec et al., 2008). 


\section{Marketing to Millennials}

The correct use of technologies and interaction through social media is mandatory to reach these generations' attention. Since Millennials spend lots of time online, digital marketing, especially using social media is the most effective way of communicating with this generation (Smith, 2011; Smith \& Brower, 2012). The e-wom is more relevant to this generation than the typical advertising techniques, particularly when focusing on social media influencers that resemble "people like me" (Gurău, 2012; Iyer et al., 2016; Moreno et al., 2017; Smith \& Brower, 2012). If fact, Millennials are constantly eager to write reviews, promoting their favorite brands and criticizing the ones that will have a negative impact on their lives as consumers (Smith, 2011; Smith \& Brower, 2012; Williams \& Page, 2012).

Appealing to Millennials consumers' emotional side using marketing campaigns that will "win their heart" and build an emotional connection is considered crucial (Iyer et al., 2016; Nowak et al., 2006a). Appeals that mirror compassion for racial and ethnic diversity should always be considered when trying to gather the Millennials' attention (Mizelle \& Beck, 2018). However, because Millennials are credited for having short attention spans and get bored easily marketing to this generation requires developing engaging content, spread through well designed and with brightly colored websites and graphics as well as constantly adjust and update brand offerings (Smith \& Brower, 2012; Williams \& Page, 2012). Although being often used, brands should avoid ads that are distracting, compulsory or interfere with what they are doing, such as pop-ups or un-closable windows because it is considered negative or annoying and trigger negative consequences regarding the way brands are perceived by this generation (Smith, 2011; Smith \& Brower, 2012).

Since this generation spends much time online and uses online purchases extensively it mandatory to develop e-commerce offers when targeting this generation (Moreno et al., 2017). The on-line strategy must also address the willingness of Millennials to engage with companies, co-creating products, designs and even participating in marketing research (Moreno et al., 2017). They tend to prefer products and services that are customized to their personality and their needs. Asking for their feedback is then a mustdo technique to gain some brand loyalty from this generation (Williams \& Page, 2012). 


\section{Proposed Model and Hypothesis}

Millennials are considered an attractive target, representing the largest consumer population (Fernandez, 2009; Moreno et al., 2017), thus it is essential to understand the best way to approach such generation from the marketing perspective (Licsandru \& Cui, 2019). With that purpose, there is a need to study the Millennials generation from the perspective of its elements, but also from the perspective of older generations, the ones that shaped the environment where the Millennials grew. In many cases, individuals from those older generations are responsible for the marketing strategies targeting MIllennials. The older generation still represents a fundamental part of those that run the businesses which produce, sell and distribute the services and goods that Millennials purchase.

According to the literature reviewed, Millennials consumers are different from other generations' consumers regarding five important points: Technology Savviness, Social and Environmental Responsibility, Status Consumption and Brand Loyalty. Therefore, hypotheses are proposed. Each hypothesis addresses one of these dimensions, exploring the existence of differences between how Millennials see themselves and how members of previous generations, namely Baby Boomers and Generation X.

\subsection{Technology Savviness}

According to the literature, Millennials are considered the most competent users of technology, especially in comparison with previous generations (Moreno et al., 2017). Since they grew up in a world of emerging and continuous development of technologies, Millennials easily became expert users, quickly learning and efficiently using all technological devices (Moreno et al., 2017; Pyöriä et al., 2017; Sago, 2010). As heavy users of technology, this generation ends up spending the majority of their time connected to at least one sort of technological device, which allows them to adapt to new technologies nearly as quickly as these are being developed (Nowak, Thach, \& Olsen, 2006b; Smith \& Brower, 2012). As such, the first hypothesis is: 
Hypothesis 1: Millennials and older generations have different perceptions regarding Millennials' Technology Savviness.

\subsection{Social and Environmental Concern}

Studied consider that Millennials live to make a positive contribution to society and the environment, characterizing them as the most social and environmental concerned generation (Nowak et al., 2006a; Ordun, 2015; Santos \& Silva, 2013). With a life motto of making the world a better place, since they grew up in a highly diversified era and are influenced by globalization, Millennials have a growing concern for equality and the protection of the environment (Nowak et al., 2006a; Ordun, 2015; Santos \& Silva, 2013). Smith (2010) found that the green side of the message in their marketing communications should be emphasized when they are targeting Millennials with their green products. This generation is also described as preferring companies that share the same concerns and considering of great importance the mission of the company or the brand when faced with the decision-making process (lyer et al., 2016; Ordun, 2015; Smith \& Brower, 2012). Accordingly, two distinct hypotheses were developed:

Hypothesis 2: Millennials and older generations have different perceptions regarding Millennials' Social Responsibility

Hypothesis 3: Millennials and older generations have different perceptions regarding Millennials' being highly Environmentally Concerned.

\subsection{Status Consumption}

Millennials are perceived as a generation that above all consumes to acquire certain status and/or image, fulfill the auto-concept, and express their lifestyle (Fernandez, 2009; Lazarevic, 2012; Moreno et al., 2017). Therefore, Millennials are regarded as being more consumption-oriented than other generations, aiming to acquire products and services that will match their personality and using brands as an extension of themselves (Gurău, 2012). Millennials tend to select the brands that will impress their 
peers, creating an image and reflecting their characteristics mainly due to being highly influenced by their peers, (Moreno et al., 2017; Smith, 2011). To assess the influence of the "People like Me" factor and status consumption propensity the fourth hypothesis is proposed:

Hypothesis 4: Millennials and older generations have different perceptions regarding Millennials' consumption to acquire status and peer influence.

\subsection{Brand Loyalty}

When compared to previous generations Millennials are typically depicted as the generation with lower loyalty towards brands due to the exposure of several price promotions and alternatives to virtually every product (Fernandez, 2009). As they consume to acquire status and reflect a certain image the choice of brands varies according to the image they are trying to provide at the moment (Moreno et al., 2017; Smith, 2011). Besides, as Millennials are highly influenced by their peers, the choice of brands also changes based on the opinion of others (e.g. digital influencers), being easily motivated to switch from one brand to another (Sago, 2010). Thus, the fifth hypothesis is proposed:

Hypothesis 5: Millennials and older generations have different perceptions regarding Millennials' brand loyalty

Table 1 presents a summary of these five hypotheses.

Table 1 - Hypotheses

\begin{tabular}{|l|l|}
\hline Concept & Hypothesis \\
\hline Technology Savviness & Millennials and older generations have different perceptions regarding Millennials' Technology Savviness \\
\hline $\begin{array}{l}\text { Social } \\
\text { Responsibility }\end{array}$ & Millennials and older generations have different perceptions regarding Millennials' Social Responsibility \\
\hline Environmental Concern & $\begin{array}{l}\text { Millennials and older generations have different perceptions regarding Millennials' being highly Environmentally } \\
\text { Concerned }\end{array}$ \\
\hline
\end{tabular}




\begin{tabular}{|l|l|}
\hline Status Consumption & $\begin{array}{l}\text { Millennials and older generations have different perceptions regarding Millennials' consumption to acquire } \\
\text { status and being highly influenced by their peers }\end{array}$ \\
\hline Brand Loyalty & Millennials and older generations have different perceptions regarding Millennials' brand loyalty \\
\hline
\end{tabular}

\section{Methodology}

To test the proposed hypotheses regarding the understanding of how Millennials see themselves in comparison to how they are perceived by other generations, a questionnaire was developed and disseminate to collect the data. The research was conducted online since it allowed to reach a large audience with lower costs and get a higher number responses more rapidly (Deutskens, De Ruyter, \& Wetzels, 2006). Several constructs were considered and applied to both Millennials to characterize the consumption patterns of the focal generation explore what vision portrayed by the other generations.

After obtaining the required answers, the results were analyzed through the statistical program IBM SPSS.

\subsection{Survey}

The survey was developed using the platform Google Forms and promoted through e-mail and social media platforms, such as Facebook, LinkedIn, and Instagram. The questionnaire was structured using multiple sections. It starts with a brief description of the topic being studied, aiming to enlighten the participants on the focal generation. After the description, respondents were asked to indicate information regarding the demographic profile, namely gender, education, age and the generational cohort they considered to belong to. This question served as a filter question to direct the members of the Millennial Generation to a questionnaire regarding the perception about their own generation whereas the members of other generations, specifically Baby Boomers or Generation X, were directed to a different section of the questionnaire, having the same questions but formulated differently in order to 
assess their view on the Millennials. Since the objective was to gather responses from Millennials and older generations, participants belonging to Generation Z were automatically directed to the end.

To measure Millennials' Technology Savviness, a five-item, five-point Likert scale (ranging from strongly disagree (1) to strongly agree (5)) the Technology Readiness Index scale from Parasuraman (Parasuraman, 2000) was used. To measure the Millennial's Social Responsibility the scale from Bucic, Harris, Arli, \& Clusters (2012) was adopted and used. Regarding the Environmental Concern, a four-item, five-point Likert Scale was constructed based on Furlow \& Knott (1996). For both, Social Responsibility and Status Consumption, the scale used were adapted from Bucic et al. (2012) and consisted of five items for the former and four-item for the later. Lastly, the measurement Millennials' Brand Loyalty, consisted of a sixitem, five-point Likert Scale, adapted from Knox and Walker (2010). The constructs, items and their respective authors can be observed in table 2.

Table 2- Constructs and Items

\begin{tabular}{|c|c|c|}
\hline Construct & Authors & Items \\
\hline $\begin{array}{l}\text { Millennials' } \\
\text { Technology Savviness }\end{array}$ & (Parasuraman, 2000) & $\begin{array}{l}\text { TS_1: People from other generations often turn to Millennials looking for } \\
\text { advice on new technologies; } \\
\text { TS_2: The Millennial generations will usually be the first to acquire new } \\
\text { technologies; } \\
\text { TS_3: Millennials will usually figure out new high-tech products without } \\
\text { help from others; } \\
\text { TS_4: Millennials keep up with the latest technological developments; } \\
\text { TS_5: Millennials tend to have fewer problems than people from other } \\
\text { generations when working with Technology; } \\
\text { TS6: People of my generation tend to have fewer problems when working } \\
\text { with new technologies than other generations. }\end{array}$ \\
\hline $\begin{array}{l}\text { Millennials' } \\
\text { Social Responsibility }\end{array}$ & (Bucic et al., 2012) & $\begin{array}{l}\text { SR_1: Millennials are willing to help those who are less fortunate; } \\
\text { SR_2: Millennials consider it very important to help other people with } \\
\text { their problems; } \\
\text { SR_3: Millennials believe that people should be more charitable towards } \\
\text { others in society; } \\
\text { SR_4: Millennials think that people should receive support from others; } \\
\text { SR_5: Millennials prefer buying from brands that help charitable causes. }\end{array}$ \\
\hline $\begin{array}{l}\text { Millennials' } \\
\text { Environmental } \\
\text { Concern }\end{array}$ & (Furlow \& Knott, 1996) & $\begin{array}{l}\text { EC_1: Millennials prefer buying organic products instead of non-organic; } \\
\text { EC_2: Millennials would rather buy a product with a recyclable content } \\
\text { label instead of one without it; } \\
\text { EC_3: Millennials tend to prefer products that are environmentally } \\
\text { friendly instead of those that are proved to harm the environment; } \\
\text { EC_4: Millennials prefer and are willing to pay more for products that } \\
\text { don't do animal testing. }\end{array}$ \\
\hline $\begin{array}{l}\text { Millennials' } \\
\text { Status Consumption }\end{array}$ & (Bucic et al., 2012) & $\begin{array}{l}\text { SC_1: Millennials consider it important that other people think well of how } \\
\text { they dress and look; }\end{array}$ \\
\hline
\end{tabular}




\begin{tabular}{|l|l|l|}
\hline & & SC_2: Millennials worry about what others think of them when deciding \\
& to buy a product; \\
& SC_3: Millennials tend to buy products from brands that will make them \\
& look good in front of their peers; \\
& SC_4: Millennials tend to feel closer to their peers when they buy the same \\
& things or use the same brands. \\
\hline \multirow{5}{*}{ Millennials' } & Millennials tend to switch brands more easily than other generations: \\
Brand Loyalty & BL_1: Due to the quality of the packaging of certain products; \\
& BL_2: Due to the differences in prices; \\
& KL_3: Due to the quality and features of a product; \\
& & BL_4: When vouchers or gifts are offered \\
& BL_5: Looking for a larger variety of products \\
& BL_6: Based on the opinion of friends, colleagues, and family \\
\hline
\end{tabular}

\subsection{Sample}

The questionnaire was promoted through social media, such as Facebook, Instagram, and Linkedln and via e-mail. The total sample consisted of 342 participants. From these, 182 were Millennials (53.8\%) and the remaining 160 were either Baby Boomers or Generation Xers (42.8\%). Regarding the Millennials, $59.3 \%$ of the participants are female (108) where $40.7 \%$ are male (74). In terms of education, the majority of Millennials hold a bachelor's degree (34,6\%), followed by a master's degree (29.1\%). On average, the Millennial participants were 26.16 years old. Among the 169 non-millennial respondents $62.5 \%$ were female (100), while only $37.5 \%$ were male (60). When it comes to education, similarly to the Millennial participants, the majority of Non-Millennials hold a bachelor's degree (40.6\%), followed by a doctoral degree (21.9\%). On average, the non-Millennial participants were 50.41 years old.

The detailed information on the sample is provided in table 3.

Table 3 - Sample characterization

\begin{tabular}{|l|l|l|l|l|l|l|l|l|l|l|}
\hline & \multicolumn{3}{|l|}{ Gender } & \multicolumn{2}{l|}{ Education } & \multicolumn{2}{l|}{ Age } \\
\cline { 2 - 10 } & Male & Female & $\begin{array}{l}\text { High school } \\
\text { or lower }\end{array}$ & $\begin{array}{l}\text { Bachelor's } \\
\text { Degree }\end{array}$ & $\begin{array}{l}\text { Master's } \\
\text { Degree }\end{array}$ & $\begin{array}{l}\text { Doctoral } \\
\text { Degree }\end{array}$ & Min & Max & Mean & SD \\
\hline Millennials & $\begin{array}{l}74 \\
(40.7 \%)\end{array}$ & $\begin{array}{l}108 \\
(59.3 \%)\end{array}$ & $60(32.9 \%)$ & $63(34.6 \%)$ & $53(29.1 \%)$ & $6(3.3 \%)$ & 18 & 37 & 26.16 & 4.38 \\
\hline $\begin{array}{l}\text { Non- } \\
\text { Millennials }\end{array}$ & $\begin{array}{l}60 \\
(37.5 \%)\end{array}$ & $\begin{array}{l}100 \\
(62.5 \%)\end{array}$ & $36(22.5 \%)$ & $65(40.6 \%)$ & $24(15 \%)$ & $35(21.9 \%)$ & 38 & 71 & 50.41 & 7.30 \\
\hline
\end{tabular}




\section{Results}

\subsection{Descriptive Statistics and reliability assessment}

Before moving to test the hypotheses a descriptive analysis for the items of the scale was performed, before progressing testing the scales' reliability (Table 4).

Table 4 - Item and scale statistics

\begin{tabular}{|c|c|c|c|c|c|c|c|c|c|c|c|}
\hline \multirow[b]{2}{*}{ Variable } & \multicolumn{5}{|c|}{ Millennials } & \multicolumn{5}{|c|}{ Non Millennials } & \multirow{2}{*}{$\begin{array}{l}\text { Cronbach } \\
\text { Alpha }\end{array}$} \\
\hline & $\mathrm{N}$ & Min. & Max. & Mean & Std.Dev. & $\mathrm{N}$ & Min. & Max. & Mean & Std.Dev. & \\
\hline \multicolumn{6}{|l|}{ Technology Savviness } & & & & & & 0.703 \\
\hline TS1 & 182 & 1 & 5 & 4.27 & 0.861 & 160 & 1 & 5 & 3.56 & 1.057 & \\
\hline TS2 & 182 & 1 & 5 & 2.07 & 0.981 & 160 & 1 & 5 & 2.28 & 1.015 & \\
\hline TS3 & 182 & 1 & 5 & 4.08 & 0.837 & 160 & 1 & 5 & 3.76 & 0.961 & \\
\hline TS4 & 182 & 2 & 5 & 4.26 & 0.741 & 160 & 1 & 5 & 3.88 & 0.893 & \\
\hline TS5 & 182 & 2 & 5 & 4.4 & 0.647 & 160 & 2 & 5 & 4.14 & 0.714 & \\
\hline TS6 & 182 & 1 & 5 & 4.26 & 0.768 & 160 & 1 & 5 & 3.47 & 1.081 & \\
\hline \multicolumn{6}{|l|}{ Social Responsibility } & & & & & & 0.843 \\
\hline SR1 & 182 & 1 & 5 & 3.55 & 0.889 & 160 & 1 & 5 & 3.07 & 0.939 & \\
\hline SR2 & 182 & 1 & 5 & 3.29 & 0.872 & 160 & 1 & 5 & 2.77 & 0.945 & \\
\hline SR3 & 182 & 1 & 5 & 3.5 & 0.833 & 160 & 1 & 5 & 2.84 & 0.875 & \\
\hline SR4 & 182 & 1 & 5 & 3.63 & 0.855 & 160 & 1 & 5 & 3.06 & 0.852 & \\
\hline SR5 & 182 & 1 & 5 & 3.02 & 1.000 & 160 & 1 & 5 & 2.93 & 0.912 & \\
\hline \multicolumn{6}{|c|}{ Environmental Concern } & & & & & & 0.881 \\
\hline EC1 & 182 & 1 & 5 & 3.42 & 0.906 & 160 & 1 & 5 & 3.53 & 0.839 & \\
\hline EC2 & 182 & 1 & 5 & 3.46 & 0.932 & 160 & 1 & 5 & 3.53 & 0.911 & \\
\hline EC3 & 182 & 1 & 5 & 3.57 & 0.982 & 160 & 1 & 5 & 3.6 & 0.841 & \\
\hline EC4 & 182 & 1 & 5 & 3.41 & 1.008 & 160 & 1 & 5 & 3.45 & 0.875 & \\
\hline \multicolumn{6}{|c|}{ Status Consumption } & & & & & & 0.784 \\
\hline SC1 & 182 & 1 & 5 & 4.12 & 0.843 & 160 & 1 & 5 & 3.53 & 1.009 & \\
\hline SC2 & 182 & 1 & 5 & 3.97 & 0.820 & 160 & 1 & 5 & 3.54 & 0.91 & \\
\hline SC3 & 182 & 1 & 5 & 4.09 & 0.809 & 160 & 1 & 5 & 3.98 & 0.858 & \\
\hline SC4 & 182 & 1 & 5 & 3.84 & 0.851 & 160 & 1 & 5 & 3.83 & 0.901 & \\
\hline \multicolumn{6}{|l|}{ Brand Loyalty } & & & & & & 0,722 \\
\hline BL1 & 182 & 1 & 5 & 3.11 & 1.061 & 160 & 1 & 5 & 3.29 & 0.948 & \\
\hline BL2 & 182 & 1 & 5 & 3.88 & 0.894 & 160 & 1 & 5 & 3.43 & 0.880 & \\
\hline BL3 & 182 & 1 & 5 & 3.98 & 0.814 & 160 & 1 & 5 & 3.63 & 0.830 & \\
\hline BL4 & 182 & 1 & 5 & 3.91 & 0.881 & 160 & 1 & 5 & 3.71 & 0.936 & \\
\hline BL5 & 182 & 1 & 5 & 3.75 & 0.860 & 160 & 2 & 5 & 3.69 & 0.762 & \\
\hline BL6 & 182 & 1 & 5 & 4.03 & 0.746 & 160 & 1 & 5 & 3.71 & 0.836 & \\
\hline
\end{tabular}


The reliability of the scales was assessed using Cronbach's Alpha coefficient (Gliem \& Gliem, 2003). Which needs to be higher than 0.707. The results show that after deleting one item for Technology Savviness all constructs were considered reliable. The detailed reliability can be found in table 4 .

\subsection{Hypotheses Testing}

To test the hypotheses, an independent samples t-test was conducted, aiming to analyze if statistically significant differences exist between Millennials and non-Millennials considering as cutoff the 0.05 significance level. Table 6 reports the results for the t-test.

Table 5 - Hypothesis Analysis

\begin{tabular}{|c|c|c|c|c|c|c|}
\hline Construct & Generation & $\mathrm{N}$ & Mean & $\begin{array}{l}\text { Standard } \\
\text { Deviation }\end{array}$ & $p$-value & $\begin{array}{l}\text { Supports } \\
\text { Hypothesis }\end{array}$ \\
\hline \multirow{2}{*}{$\begin{array}{l}\text { Technology } \\
\text { Savviness }\end{array}$} & Millennials & 182 & 4.25 & 0.521 & \multirow{2}{*}{0.000} & \multirow{2}{*}{ YES } \\
\hline & Non-Millennials & 160 & 3.76 & 0.597 & & \\
\hline \multirow{2}{*}{$\begin{array}{l}\text { Social } \\
\text { Responsibility }\end{array}$} & Millennials & 182 & 3.39 & 0.657 & \multirow{2}{*}{0.000} & \multirow{2}{*}{ YES } \\
\hline & Non-Millennials & 160 & 2.93 & 0.731 & & \\
\hline \multirow{2}{*}{$\begin{array}{l}\text { Environmental } \\
\text { Concern }\end{array}$} & Millennials & 182 & 3.46 & 0.810 & \multirow{2}{*}{0.476} & \multirow{2}{*}{ NO } \\
\hline & Non-Millennials & 160 & 3.52 & 0.759 & & \\
\hline \multirow{2}{*}{$\begin{array}{l}\text { Status } \\
\text { Consumption }\end{array}$} & Millennials & 182 & 4.00 & 0.617 & \multirow{2}{*}{0.000} & \multirow{2}{*}{ YES } \\
\hline & Non-Millennials & 160 & 3.71 & 0.748 & & \\
\hline \multirow{2}{*}{ Brand Loyalty } & Millennials & 182 & 3.78 & 0.556 & \multirow{2}{*}{0.001} & \multirow{2}{*}{ YES } \\
\hline & Non-Millennials & 160 & 3.57 & 0.574 & & \\
\hline
\end{tabular}

The results in table 5 indicate that that Millennials and older generations have different perceptions regarding Millennial technology savviness, social responsibility, status consumption, and brand loyalty. Environmental concern was the only dimension were the self-opinion of Millennials did not differ from the other generations. These results suggest that in almost all dimensions the institutional logic and generational gap applies, however when considering the environment concerns the positioning of both generations is similar. 


\section{Discussion and Conclusions}

The main objective of this study focuses on the understanding of the different ways Millennials are perceived and try to figure out which is the best characterization of this extremely important generational cohort. According to the results except for Environmental Friendliness, non-Millennials will usually have a lower consideration of Millennials than what they have of themselves. This might be due to differences in education levels which influence the mindset that Baby Boomers and Generation Xers have when dealing with Millennials. These differences stand for cultural environments reported in other studies. The perception of others regarding the focal generation reveals that Millennials are not seen as positively as they seem to think they are, which might be linked to the highly commended characteristic in the literature that stating that Millennials are self-centered and used to instant gratification, and, therefore, will tend to have an attitude of self-appraisal when referring to characteristics of their own generation (Gurău, 2012; lyer et al., 2016). These results go in line with the ones by Twenge, Campbell, and Freeman (2012) that also supported the idea of Millennials as the "generation me".

This issue was expected to influence the response to the question of how accurate the Millennials are characterized when compared to their perception of themselves. When it comes to the Millennials Technology Savviness, the literature agrees upon the fact that Millennials are the most technologically developed generation (Mizelle \& Beck, 2018; Moreno et al., 2017), having tremendous ease for using any technological device and always being up to date with the latest technological developments (Nowak et al., 2006b; Pyöriä et al., 2017; Sago, 2010). Thus, the findings confirm that national environments marked by similarities in terms of regulatory, cognitive and normative pillars give raise to a country institutional profile that tends to favor comparative national business systems, based on institutional embeddedness

(Dacin, Goodstein, \& Scott, 2002) As expected, the data collected from the surveys support this attribute since both the Millennials and the non-Millennial participants consider this generation to be highly technology savvy.

Besides highly technology savvy, Millennials are also depicted in the literature as being the most socially and environmentally concerned generation, to the point of preferring to acquire products from brands that share these value and aiming to make a positive contribution to society (Ordun, 2015; Santos \& Silva, 2013; Smith \& Brower, 2012). The results reinforce this evidence by showing that the participants 
seem to consider that Millennials do care about the environment and social causes, but not as much as they are usually portrayed to, at least not enough to add significant weight to the decision-making process.

When asked about the consumption to acquire status or reflect a certain image, and being influenced by their peers, the results support the literature, providing evidence that this generation tends to acquire products that will make them look good in front of their peers, trying to establish a certain image and even reflect certain aspects of their personalities through the brands they use (Fernandez, 2009; Gurău, 2012; Lazarevic, 2012; Ordun, 2015).

Lastly, one aspect that seems to perfectly define the Millennials, at least in the studied literature is that this generation lacks brand loyalty, being considered the least loyal generation when it comes to the brands they use (Moreno et al., 2017; Sago, 2010; Smith, 2011), which can be due to higher exposure to price promotions, but is also related to the previous aspect that pays respect to the influence of their peers(Fernandez, 2009; Gurău, 2012; Smith, 2010). When confronted with this lack of loyalty towards brands and companies, Millennials seem to agree that they will easily switch brands, mainly due to the opinion of their peers, highlighting the crucial role of digital influencer have upon this generation. In fact, Millennials are commonly depicted as having a negative image related to certain practices of Digital Marketing and is firmly believed that this generation, for being influenced by the "people like me", will be positively or negatively influenced by the reviews written by their peers (Smith, 2010, 2011; Smith \& Brower, 2012; Williams \& Page, 2012). Indeed, the results of the questions apply only to Millennials show that they, tend to view in negative manner pop-ups and video adverts.

\section{Managerial Implications}

The online environment is highly dynamic and given that Millennials are not brand loyal they will rely upon trends and popularity of brands (Gurău, 2012; Moreno et al., 2017). Consequently, brands should always pay attention to competitors, since there is extensive exposure to price promotions, hence, competitive pricing is a must to retain this generation (Fernandez, 2009; Moreno et al., 2017; Smith \& Brower, 2012), regardless of the institutional setting, that is - the rules of the game - which seem to be more deterministic on this sense that some studies demonstrated (Dacin, Kostova, \& Roth, 2008). 
For example, this study supports the fact that brands shouldn't be too concerned with the traditional ways of advertising. This type of advertising can be considered ineffective since Millennials will choose to spend their money on products that they will know will be worth it, looking for the opinion of the previously mentioned people like them, these being both their peers, as well as social media influencers. They firmly believe that the reviews written by others are significantly more reliable than the advertising put together by the brand itself. As a consequence, it is crucial to understand the best ways to encourage this generation, to engage them in the analysis of their own needs, in the innovation process, the production of value proposals, the marketing strategy targeting them and even in the invitation to write reviews regarding products and services they have purchased.

In other words, this study can help companies to more efficiently understand how Millennials feel about themselves, develop better and longer-lasting relationships with this attractive generational cohort, and thus contributing somehow to settle some order in this new world that has been subject to a radical set of social and structural shifts in the last three years, with a special emphasis for the last three months due to the unprecedented Covid-19 pandemic that struck the all entire world, proving that we are all in one single boat.

\section{Limitations and Further Research}

The analysis of the current results is subjected to the consideration of some limitations. Firstly, some important characteristics may have not been considering and should be taken into consideration in future studies. Further research should be conducted aiming to explore a larger number of characteristics defining this generation. Secondly, the respondents belonging to older generations do not represent the overall members of their respective generations, especially regarding their level of education. The Baby Boomers and Generation X education levels are significantly above society's average. Hence, in case of a similar comparison of different generations' points of view, one should focus on gathering a sample of respondents that would more accurately reflect these generations.

Another limitation of this research is the sample considered in this study consisting of only Portuguese participants, which narrows the topic down to only a small percentage of the Millennials worldwide, 
creating a barrier when describing this generation's behavior since the environment in what specific Millennials grow up highly influences their behaviors and characteristics. Having a broader sample, with a significant number of worldwide populations would allow a much more adequate characterization of such generation. Therefore, further research should have a higher focus on Millennials from different countries, broadening the sample and gathering responses from a higher and much more diverse number of members of such generation. This would provide a much more accurate description of them, and, consequently, a better understanding of what the word Millennials means.

\section{References}

Arthur, W. (1994). Increasing Returns and Path Dependence in the Economy. Ann Arbor, MI: University of Michigan Press.

Barnes, S. J., \& Pressey, A. D. (2016). Cyber-mavens and online flow experiences: Evidence from virtual worlds. Technological Forecasting and Social Change, 111, 285-296. https://doi.org/10.1016/j.techfore.2016.07.025

Broido, E. M. (2004). Understanding diversity in millennial students. New Directions for Student Services, 2004(106), 73-85. https://doi.org/10.1002/ss.126

Bucic, T., Harris, J., \& Arli, D. (2012). Ethical Consumers Among the Millennials: A CrossNational Study. Journal of Business Ethics, 110(1), 113-131. https://doi.org/10.1007/s10551-011-1151-z

Cleveland, M., Laroche, M., \& Papadopoulos, N. (2015). You are what you speak? Globalization, multilingualism, consumer dispositions and consumption. Journal of Business Research, 68(3), 542-552. https://doi.org/10.1016/j.jbusres.2014.09.008

Dacin, M. T., Goodstein, J., \& Scott, W. R. (2002). Institutional theory and institutional change: Introduction to the special research forum. Academy of Management Journal, 45(1), 45-57. https://doi.org/10.5465/amj.2002.6283388

Dacin, M. T., Kostova, T., \& Roth, K. (2008). Institutional Theory in the Study of Multinational Corporations: A Critique and new Directions. Academy of Management Review, 33(4), 994-1006.

Dagher, V. (2014). Talking philanthropy with millennials. Https://Www.Wsj.Com/Articles/Talking-Philanthropy-with-Millennials-1411132805. Retrieved from https://www.wsj.com/articles/talking-philanthropy-with-millennials- 


\section{5}

Debevec, K., Schewe, C. D., Madden, T. J., \& Diamond, W. D. (2008). I, me, and mine-how products become consumers' extended selves. Journal of Consumer Behaviour, 12(4), 253-266. https://doi.org/10.1002/cb

Deutskens, E., De Ruyter, K., \& Wetzels, M. (2006). An assessment of equivalence between online and mail surveys in service research. Journal of Service Research, Vol. 8, pp. 346-355. https://doi.org/10.1177/1094670506286323

Eastman, J. K., \& Liu, J. (2012). The impact of generational cohorts on status consumption: An exploratory look at generational cohort and demographics on status consumption. Journal of Consumer Marketing, 29(2), 93-102. https://doi.org/10.1108/07363761211206348

Fernandez, P. R. (2009). Impact of Branding on Gen Y's Choice of Clothing. Journal of the South East Asia Research Centre for Communications and Humanities, 1(1), 79-95.

Furlow, N. E., \& Knott, C. (1996). Who's Reading the Label? Millennials' Use of Environmental Product Labels. Journal of Applied Business and Economics, 10, 1-12.

Gliem, J. a, \& Gliem, R. R. (2003). Calculating, Interpreting, and Reporting Cronbach's Alpha Reliability Coefficient for Likert-Type Scales,. 2003 Midwest Research to Practice Conference in Adult, Continuing, and Community Education, (1992), 82-88. https://doi.org/10.1109/PROC.1975.9792

Gurău, C. (2012). A life-stage analysis of consumer loyalty profile: Comparing Generation X and Millennial consumers. Journal of Consumer Marketing, 29(2), 103-113. https://doi.org/10.1108/07363761211206357

Hallman, H. L. (2017). Millennial teachers and multiculturalism: considerations for teaching in Uncertain Times. Journal for Multicultural Education, 11(3), 194-205. https://doi.org/10.1108/JME-10-2016-0055

Iyer, R., Eastman, J. K., Monteiro, H., Rottier, H., \& Zokarkar, S. S. (2016). Perceptions of Millennials' Media Attitudes and Use: A Comparison of U.S. and Indian Millennials. The Marketing Management Journal, 26(2), 69-85.

Knox, S., \& Walker, D. (2001). Measuring and managing brand loyalty. Journal of Strategic Marketing, 128, 111-128. https://doi.org/10.1080/09652540010029962

Lazarevic, V. (2012). Encouraging brand loyalty in fickle generation $Y$ consumers. Young Consumers, 13(1), 45-61. https://doi.org/10.1108/17473611211203939 
Licsandru, T. C., \& Cui, C. C. (2019). Ethnic marketing to the global millennial consumers: Challenges and opportunities. Journal of Business Research, 103(xxxx), 261-274. https://doi.org/10.1016/j.jbusres.2019.01.052

McGlone, T., Spain, J. W., \& McGlone, V. (2011). Corporate Social Responsibility and the Millennials. Journal of Education for Business, 86(4), 195-200. https://doi.org/10.1080/08832323.2010.502912

Mizelle, E., \& Beck, M. S. (2018). Engaging Millennials : Best Practice for Using Pinterest. Teaching and Learning in Nursing, 13(1), 58-62. https://doi.org/10.1016/j.teln.2017.09.006

Moreno, F. M., Lafuente, J. G., Carreón, F. Á., \& Moreno, S. M. (2017). The Characterization of the Millennials and Their Buying Behavior. International Journal of Marketing Studies, 9(5), 135. https://doi.org/10.5539/ijms.v9n5p135

Nowak, L., Thach, L., \& Olsen, J. E. (2006a). Wowing the millennials: Creating brand equity in the wine industry. Journal of Product and Brand Management, 15(5), 316-323. https://doi.org/10.1108/10610420610685712

Nowak, L., Thach, L., \& Olsen, J. E. (2006b). Wowing the millennials: Creating brand equity in the wine industry. Journal of Product and Brand Management, 15(5), 316-323. https://doi.org/10.1108/10610420610685712

Ordun, G. (2015). Millennial (Gen Y) Consumer Behavior Their Shopping Preferences and Perceptual Maps Associated With Brand Loyalty. Canadian Social Science, 11(4), 1-16. https://doi.org/10.3968/pdf_294

Palfrey, J., \& Gasser, U. (2008). Born digital: Understanding the first generation of Digital Native. New York: Basic Books.

Parasuraman, A. (2000). Technology Readiness Index (Tri). Journal of Service Research, 2(4), 307-320. https://doi.org/10.1177/109467050024001

Pyöriä, P., Ojala, S., Saari, T., \& Järvinen, K.-M. (2017). The Millennial Generation. SAGE Open, 7(1), 215824401769715. https://doi.org/10.1177/2158244017697158

Reisenwitz, T., \& Iyer, R. (2009). Differences in Generation X and Generation Y: Implications for the organization and marketers. Marketing Management Journal, 19(2), 91-103. https://doi.org/10.6007/IJARBSS/v3-i11/319

Sago, B. (2010). The Influence of Social Media Message Sources on Millennial Generation Consumers. International Journal of Integrated Marketing Communications, 2(2), 7- 
18.

Salomon, R., \& Wu, Z. (2012). Institutional distance and local isomorphism strategy. Journal of International Business Studies, 43(4), 343-367. https://doi.org/10.1057/jibs.2012.3

Santos, M. C. dos, \& Silva, S. C. e. (2013). The 3 C'S Model Of Millennials Brand Awareness. Working Papers de Gestão (Management Working Papers), 1-13. Retrieved from http://ideas.repec.org/p/cap/mpaper/022013.html

Scheresberg, C. D. B., Lusardi, A., \& Yakoboski, P. J. (2014). College-educated millennials: An overview of their personal finances. Financial Services, (February), 1-38.

Smith, K. T. (2010). An examination of marketing techniques that influence millennials' perceptions of whether a product is environmentally friendly. Journal of Strategic Marketing, 18(6), 437-450. https://doi.org/10.1080/0965254X.2010.525249

Smith, K. T. (2011). Digital marketing strategies that Millennials find appealing, motivating, or just annoying. Journal of Strategic Marketing, 19(6), 489-499. https://doi.org/10.1080/0965254X.2011.581383

Smith, K. T. (2014). Millennials' interpretations of green terminology. Academy of Marketing Studies Journal, 18(1), 55-68.

Smith, K. T., \& Brower, T. R. (2012). Longitudinal study of green marketing strategies that influence Millennials. Journal of Strategic Marketing, 20(6), 535-551. https://doi.org/10.1080/0965254X.2012.711345

Tapscott, D. (1998). Growing up digital: The rise of the net generation. New York: McGrawHill.

Twenge, J. M., Campbell, W. K., \& Freeman, E. C. (2012). Generational differences in young adults' life goals, concern for others, and civic orientation, 1966-2009. Journal of Personality and Social Psychology, 102(5), 1045-1062. https://doi.org/10.1037/a0027408

Williams, K. C., \& Page, R. A. (2012). Marketing to the Generations. Journal of Behavioral Studies in Business, 4(8), 72-97. https://doi.org/10.18394/iid.80342

Wood, S. (2000). Generation Z as Consumers: Trends and Innovation. 2-4.

Young, A. M., \& Hinesly, M. D. (2012). Identifying Millennials' key influencers from early childhood: Insights into current consumer preferences. Journal of Consumer Marketing, 29(2), 146-155. https://doi.org/10.1108/07363761211206393 